\title{
Globalização e Governo das Universidades
}

$\mathrm{N}$ AS DUAS ÚlTIMAS DECADAS, A GLOBALIZAÇão das economias e a transformação do conhecimento num factor essencial de competitividade económica, associadas à emergência do neo-liberalismo provocaram uma alteração significativa das funções sócio-económicas da Universidade com uma mudança do equilíbrio das funçōes sociais e económicas da universidade a favor destas últimas.

O Estado quer agora forçar as Universidades a serem "relevantes", a aumentarem a sua sensibilidade ao mundo exterior, a estabelecerem ligações com o sector empresarial, no sentido em que isso significa um reforço da função económica da Universidade. Ao mesmo tempo, a forma tradicional de governo participativo da governação universitária tornou-se alvo de críticas ferozes, sendo considerado alternadamente ou em simultâneo como ineficiente, corporativa, insensível às necessidades da sociedade e incapaz de evitar a diminuição da qualidade do ensino e da investigação.

Os sectores neoliberais criticam o Estado providência dizendo que as agências públicas são ineficientes e produzem desperdícios, quer devido a sobreprodução, quer devido a produção ineficiente, a que se junta a crença de que os subsídios vão muitas vezes parar aos bolsos de quem não os merece. Os serviços públicos, vistos como incapazes, cedem o passo ao sector privado visto como mais apto para resolver os problemas de forma mais eficiente. Por exemplo, assistiu-se em Inglaterra a uma onda de privatizações que atingiu servi- ços que eram tradicionalmente públicos, como os caminhos de ferro, os serviços de saúde, o ensino e os serviços prisionais.

A globalização crescente da economia tem um efeito negativo sobre a segurança de emprego e a capacidade reivindicativa dos trabalhadores, gerando um fenómeno de incerteza sobre os padrões de emprego e afectando, de forma significativa, os padrões económi$\cos$ que permitiram o crescimento e consolidação do que Stephen Ball (1998) chama "a nova classe média." Segundo Jordan (1994), os "futuros imaginados da classe média e dos seus descendentes" estāo a desfazer-se em fumo devido ao congestionamento não planeado das profissões e dos lugares de gestão.

Um dos efeitos perversos deste fenómeno tem sido a diminuição do apoio dado pela nova classe média às medidas de democratização das políticas sociais da educação. Neste processo, as escolas e os seus professores tornam-se os bombos da festa, perante o gáudio de uma classe política que há muito esqueceu que a massificação se fez com diminuição sustentada dos financiamentos por aluno, em nome de mais do que duvidosos ganhos de produtividade, e que muitos dos problemas existentes derivam da sua incompetência como legisladores.

As iniciativas no sentido dos rankings de escolas e da promoção da escolha das escolas pelos pais enquadram-se neste tipo de movimentações, e procuram dar uma nova vantagem competitiva às classes média e superior. Estudos feitos sobre o sistema inglês mostram que a promoção da escolha parental se traduziu na defesa das classes mais favorecidas, uma vez que as outras não têm conhecimentos, cultura ou mesmo capacidade para beneficiar plenamente das novas políticas. Na Nova Zelândia, outra vítima recente da fúria neoliberal, o novo Ministro da Educação, Steve Maharey, proclamou a falência do modelo de mercado para o ensino terciário já que os seus efeitos tinham sido catastróficos.

Nos EUA, alguns estados têm feito experiências com modelos de vouchers para o ensino secundário - algo que o sector privado reclama para o nosso ensino superior, numa tentativa de defesa dos seus interesses. Algumas daquelas iniciativas têm sido declaradas inconstitucionais com base na Constituição Americana determinar a separação entre Igreja e Estado, pelo que os vouchers podem ser vistos como uma forma de transferir dinheiro dos impostos para escolas de origem religiosa. Um primeiro caso acaba de chegar ao Supremo Tribunal, sendo curioso saber qual será a decisão final.

Tudo isto veio a afectar fortemente as universidades. O ensino passou de constituir um direito a ser um serviço e as universidades as fornecedoras desses serviços, ao passo que os alunos assumem, de forma crescente, o papel de clientes. Por outras palavras, a Universidade perdeu a sua condição de instituição social para se transformar numa

\footnotetext{
* Faculdade de Ciências. Universidade do Porto
} 
mera organização social ou numa entidade administrada.

Do que não há dúvida é de que as Universidades enfrentam hoje um desafio muito complexo, não sendo possível prever em que forma encontrarão uma nova conformação estável. Mas será a via neoliberal a solução para os problemas? Em países onde a lógica do mercado foi imposta para resolver os problemas da gestão e eficiência do sector público começa a ser aparente que os resultados não corresponderam às ex- pectativas. As consequências das privatizações dos caminhos de ferro britâni$\cos$, do fornecimento de água e de energia na Califórnia e dos serviços de educação na Nova Zelândia, ou os resultados em termos de custo e de qualidade da privatização de serviços de saúde na Austrália e no Reino Unido dão que pensar. No início do novo milénio crescem as interrogações sobre se esse será o caminho que levará a um mundo melhor, e se essas reformas resultaram de opções técnicas racionais ou de mera ideologia. E a própria con- fiança (ou fé) na superioridade dos mecanismos de gestão do sector privado foi recentemente abalada por episódios como a espetacular falência da ENRON, ou o papel pouco claro da Arthur Andersen na auditoria das contas.

Parafraseando uma antiga anedota a propósito do comunismo responderei à pergunta Quem inventou o neo-liberalismo, os políticos ou os cientistas? dizendo que foram certamente os políticos, pois os cientistas teriam experimentado primeiro em animais de laboratório.

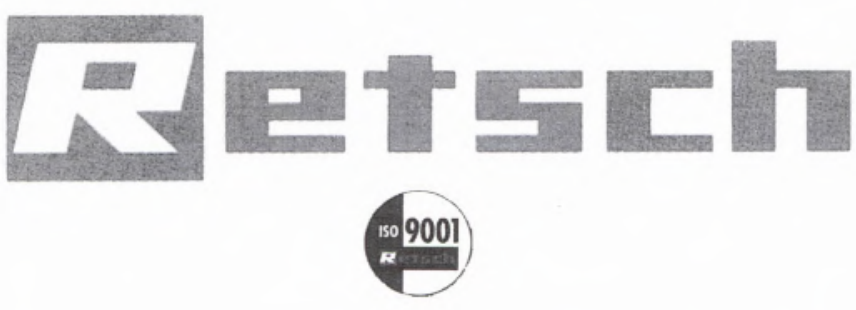

Moinhos
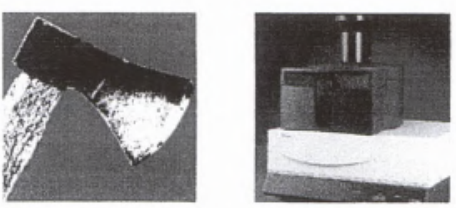

Agitadores de peneiros/peneiros
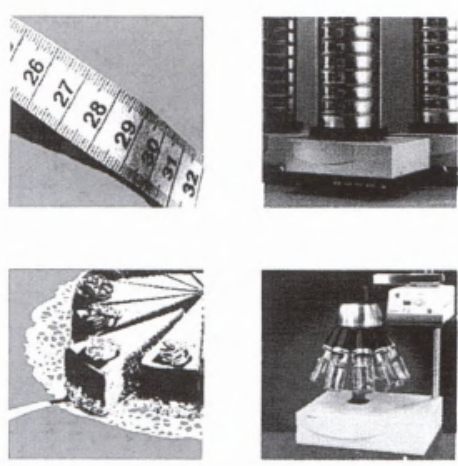

Divisores de amostras

Análise granulométrica automática CAMSIZER / Crystalsizer

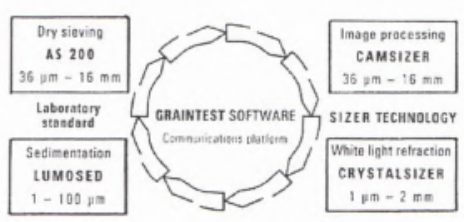

Peça-nos o contacto do agente mais próximo, através dos telefones:

21-352 7293 http://

Campo Mártires da Pátria, 109 Rua do Vilarinho, 1235 • 4100-517, Porto

\section{2-618 4232}

0 Importador Exelusiva 